\title{
Faktor-faktor yang berhubungan dengan kejadian ketuban pecah dini di IGD maternal RSUD dr. Drajat Prawiranegara
}

\author{
Nuria Fitri Adista ${ }^{1 *}$, Ika Apriyanti ${ }^{2}$, Vega Muhida ${ }^{3}$ \\ 1,2,3 Politeknik Kesehatan Aisyiyah Banten
}

\section{INFORMASI ARTIKEL:}

\begin{tabular}{l}
\hline Riwayat Artikel: \\
Tanggal diterima, 19 Juli 2021 \\
Tanggal direvisi, 24 November 2021 \\
Tanggal dipublikasi, 5 Desember 2021 \\
\hline
\end{tabular}

\section{Kata kunci:}

Usia Ibu,

Gravida,

Preeklampsia,

Anemia,

Sungsang,

gemelli,

ketuban pecah dini

$10.32536 /$ jrki.v5i2.182

Keyword:

Maternal age,

Gravida,

Preeclampsia,

Anemia,

Breech,

gemelli,

premature rupture of membranes

\section{ABSTRAK}

Latar belakang: Kematian Ibu sekitar 10-20\% disebabkan oleh infeksi. Salah satu penyebab infeksi adalah Ketuban Pecah Dini. Penyebab Ketuban Pecah Dini (KPD) belum diketahui secara pasti. Faktor risiko KPD adalah infeksi yang terjadi secara langsung pada selaput ketuban dari vagina atau serviks, fisiologi selaput ketuban yang abnormal, serviks inkompetensia, kelainan letak janin, usia, faktor golongan darah, faktor graviditas, usia kehamilan, merokok, preeklampsia, keadaan sosial ekonomi, pendarahan antepartum, riwayat abortus dan persalinan preterm sebelumnya, riwayat KPD sebelumnya, defisiensi gizi yaitu tembaga atau asam askorbat, ketegangan rahim yang berlebihan, kesempitan panggul, kelelahan ibu dalam bekerja, hidramnion, kehamilan ganda, pendular abdomen serta trauma yang didapat misalnya hubungan seksual, pemeriksaan dan amniosintesis. Tujuan penelitian: Untuk mengetahui faktor yang berhubungan dengan kejadian ketuban pecah dini. Metode: Penelitian analitik dengan metode case - control. Populasi berjumlah 2.219 yakni ibu bersalin yang mengalami ketuban pecah dini. Jumlah sampel 194 ibu bersalin yang terdiri dari 97 kasus dan 97 kontrol. Sampel penelitian diambil dengan teknik consecutive sampling. Penelitian ini berupa data sekunder, instrumen penelitian menggunakan daftar checklist, analisis data univariat, bivariat, dan multivariat. Uji statistik yang digunakan adalah uji regresi logistik berganda dengan model prediksi. Hasil: Dari analisis univariat didapatkan hasil bahwa $66 \%$ ibu yang mengalami KPD berusia $<20$ atau $>35$ tahun, 67\% dengan riwayat gravida primipara, mengalami $54 \%$ mengalami preeklamsi, $31 \%$ ibu dengan riwayat anemia, $19 \%$ letak sungsang dan $10 \%$ gemelli. Terdapat hubungan yang signifikan antara variabel usia ibu, gravida, preeklampsi, anemia, letak sungsang, gemeli, dengan kejadian ketuban pecah dini ( $p$-value $<0.05)$. Simpulan: Variabel yang paling dominan mempengaruhi kejadian ketuban pecah dini yaitu variabel gravida dengan nilai OR dari gravida adalah $=8,773$.

Background: Maternal mortality is about $10-20 \%$ caused by infection. One of the causes of infection is premature rupture of membranes. The cause of premature rupture of membranes (PROM) is certainly unknown. Risk factors for PROM are infections that occur directly in the amniotic membranes from the vagina or cervix, abnormal physiology of the membranes, cervical incompetence, fetal position abnormalities, age, blood group factors, gravidity factors, gestational age, smoking, preeclampsia, socioeconomic conditions, antepartum bleeding, previous history of abortion and preterm delivery, history of the previous PROM, nutritional deficiency, namely copper or ascorbic acid, excessive uterine tension, pelvic narrowing, maternal fatigue at work, hydramnios, multiple pregnancies, pendular abdomen and trauma such as sexual intercourse, examination, and amniocentesis. Objectives: To determine the factors associated with the incidence of premature rupture of membranes. Methods: This research used the analytical method of case-control. The population was 2,219 consisting of mothers who experienced premature rupture of membranes. The number of samples was 194 mothers who gave birth consisting of 97 cases and 97 controls. The research sample was taken by consecutive sampling techniques. This research consisted of secondary data, and the research instrument used a checklist, analysis of univariate, bivariate, and multivariate data. The statistical test used was a multiple logistic regression test with a predictive model. Results: From the univariate analysis, it was found that $66 \%$ of mothers with PROM aged $<20$ or $>35$ years, $67 \%$ with a history of primiparous gravida, 54\% experienced preeclampsia, $31 \%$ mothers with a history of anemia, $19 \%$ breech position, and 10\% Gemelli. There is a significant correlation between the variables of maternal age, gravida, preeclampsia, anemia, breech position, Gemelli, and the incidence of premature rupture of membranes ( $p$ value $<0.05)$. Conclusion: The predominant variable affecting the incidence of premature rupture of membranes is the gravida variable with the OR value of gravida $=8,773$. 


\section{Pendahuluan}

Penyebab langsung kematian ibu tertinggi di Indonesia, seperti halnya di negara lain adalah perdarahan, infeksi, dan eklampsia dengan persentase kejadian perdarahan sekitar $60-70 \%$, preeklampsia dan eklampsia 10 - 20\%, serta infeksi sekitar 10-20\% (Saifudin, 2017).

Infeksi merupakan penyebab kematian ibu dan kematian bayi di Indonesia, dimana salah satu penyebab terjadinya infeksi pada ibu dan bayi adalah ketuban pecah dini (KPD). KPD merupakan salah satu komplikasi kehamilan yang paling sering ditemui. Insiden KPD adalah 2,7\%- 17\%, bergantung pada lama periode fase laten yang digunakan untuk menegakkan diagnosis KPD. Angka kejadian kasus KPD terjadi lebih tinggi pada wanita dengan serviks inkompeten, polihidramnion, dan malpresentasi janin. Terdapat beberapa faktor penyebab KPD, antara lain riwayat KPD sebelumnya, perdarahan pervaginam, dan riwayat operasi saluran genetalia. Dalam keadaan normal, $8-10 \%$ perempuan hamil aterm akan mengalami ketuban pecah dini (Prawirohardjo, 2016).

Angka Kematian Ibu (AKI) berhubungan dengan berbagai komplikasi yang menyertainya baik selama kehamilan, persalinan dan nifas. Perdarahan, preeklamsia, dan infeksi menyumbang sepertiga dari semua kematian ibu. Diperkirakan sekitar 20\% dari kehamilan akan mengalami komplikasi dan salah satu komplikasi pada kehamilan maupun persalinan adalah KPD (RI, 2017).

Indikator kesehatan suatu negara ditentukan oleh angka kematian ibu karena kehamilan, persalinan, dan nifas serta kematian bayi dan balita di Indonesia hingga kini masih tergolong tinggi. Upaya yang dapat dilakukan pemerintah untuk mencegah terjadinya KPD yaitu dengan cara memberikan pendidikan kesehatan pada ibu hamil tentang kehamilan, persalinan. Menganjurkan agar ibu hamil secara rutin melakukan Antenatal Care (ANC) ke tempat pelayanan kesehatan selama kehamilan berlangsung. Ibu perlu juga memperhatikan aktivitas sehari-hari sehingga persalinannya bisa berjalan dengan lancar dan

\footnotetext{
* Korespondensi penulis.

Alamat E-mail: nurino@ymail.com
}

tidak terjadi hal-hal yang tidak diinginkan (RI, 2017).

Insiden KPD di Indonesia berkisar 4,5\%-6\% dari seluruh kehamilan tahun 2018. Hasil penelitian lain di Indonesia bahwa dari seluruh kehamilan, 5-10\% mengalami KPD. Pada persalinan kurang bulan, sepertiga diantaranya mengalami KPD. 60\% KPD di antaranya terjadi pada kehamilan cukup bulan. Pada kehamilan dengan KPD, sebagian besar kasus ditemukan mulut rahim yang belum matang, $30-40 \%$ mengalami gagal induksi sehingga diperlukan tindakan operasi, sedangkan sebagian lain mengalami hambatan kemajuan persalinan dengan peningkatan risiko infeksi pada ibu dan janin. Kejadian amnionitis dilaporkan 15-23\% pada penderita hamil dengan KPD (Purba, 2015).

Penyebab KPD belum diketahui secara pasti, namun yang menjadi faktor risikonya adalah infeksi yang terjadi secara langsung pada selaput ketuban dari vagina atau serviks, fisiologi selaput ketuban yang abnormal, serviks inkompetensia, kelainan letak janin, usia, faktor golongan darah, faktor graviditas, usia kehamilan, merokok, preeklampsia, keadaan sosial ekonomi, pendarahan antepartum, riwayat abortus dan persalinan preterm sebelumnya, riwayat KPD sebelumnya, defisiensi gizi yaitu tembaga atau asam askorbat, ketegangan rahim yang berlebihan, kesempitan panggul, kelelahan ibu dalam bekerja, hidramnion, kehamilan ganda, pendular abdomen serta trauma yang didapat misalnya hubungan seksual, pemeriksaan dan amniosintesis (Wiknjosastro, 2014).

Faktor usia mempunyai pengaruh yang erat dengan perkembangan alat-alat reproduksi wanita. Usia reproduksi sehat yaitu usia $20-35$ tahun, merupakan usia yang paling aman bagi seorang wanita untuk hamil dan melahirkan. Usia yang terlalu muda ( $<20$ tahun) atau terlalu tua (>35 tahun) mempunyai risiko yang lebih besar untuk melahirkan bayi yang kurang sehat dan rentan terjadi infeksibaik pada ibu maupun bayi

Graviditas merupakan frekuensi kehamilan yang pernah dialami seorang ibu. Ibu primigravida (ibu yang hamil pertama kali) akan cenderung merasa cemas dengan kehamilannya. Pada primigravida, kurangnya imformasi dan komunikasi yang buruk mempengaruhi kesiapan wanita dalam menghadapi kehamilan. Ibu primigravida lebih berisiko untuk mengalami stress, dimana stress 
dapat merupakan faktor yang berkontribusi dalam komplikasi kehamilan maupun komplikasi persalinan. 140 ibu primigravida 80 ibu mengalami KPD atau sebesar 57,1\%. (Al-Hussain, Tarek Khalaf, Sahar Nagieb Mohamed, Hamida Alam El-dien, 2012).

Manuaba I Gde, (2012) menyatakan bahwa akibat preeklampsia yang utama adalah vasokontriksi arterial yang menyebabkan kenaikan tekanan darah dan menurunnya pasokan darah yang efektif pada banyak organ serta jaringan tubuh, termasuk plasenta. Plasenta dapat mengalami infark sehingga membatasi jumlah oksigen dan nutrien yang tersedia bagi bayi. Retardasi pertumbuhan intrauteri dapat terjadi dan keadaan hipoksia membuat janin tidak mampu untuk menahan stres persalinan yang normal yang dapat menyebabkan KPD. Hasil penelitian Ayu, (2018) menunjukkan bahwa terdapat hubungan antara preeklampsia dengan kejadian KPD dengan $p$-value $=0.023(p<0,05)$.

Anemia selama kehamilan menyebabkan ibu hamil tidak begitu mampu untuk menghadapi kehilangan darah dan membuatnya rentan terhadap infeksi. Berdasarkan penelitian Wulandari (2016), ibu yang mengalami anemia berisiko 3,33 kali lebih tinggi untuk mengalami KPD dibandingkan dengan ibu yang tidak mengalami anemia.
Kelainan letak janin (malpresentasion) dapat menjadi salah satu faktor kejadian KPD. Salah satu contoh malpresentasion adalah letak sungsang. Pada letak sungsang, bokong menempati serviks uteri, dengan keadaan ini pergerakan janin terjadi dibagian terendah karena keberadaan kaki janin yang menempati daerah serviks uteri sedangkan kepala janin akan mendesak fundus uteri yang dapat menekan diafragma. Keadaan ini menyebabkkan timbulnya rasa sesak pada ibu hamil yang dapat meningkatkan ketegangan tekanan intra uterin sehingga menyebabkan terjadinya KPD (Antonius, 2017).

Berdasarkan hasil survey data dengan menggunakan data sekunder registrasi IGD Maternal RSUD.dr.Dradjat Prawiranegara Serang yang dilakukan oleh peneliti, diperoleh bahwa terdapat 5.963 kejadian komplikasi persalinan pada periode Januari-Desember 2019. Kasus ketuban pecah dini selama 1 tahun terakhir sebanyak 2.219 kasus (37\%). Oleh karena itu penting diamati, tentang hubungan ketuban pecah dini dengan Usia Ibu, Gravida, Preeklampsia, Anemia, Sungsang, dan kehamilan ganda (gemelli).

\section{Metode penelitian}

Metode yang digunakan adalah penelitian analitik dengan metode case - control. Populasi berjumlah 2.219 yakni ibu bersalin yang mengalami ketuban pecah dini. Jumlah sampel 194 ibu bersalin yang terdiri dari 97 kasus dan 97 kontrol. Subyek penelitian diambil dengan teknik consecutive sampling. Penelitian ini menggunakan data sekunder. Instrumen penelitian menggunakan daftar checklist. Analisis data univariat, bivariat, dan multivariat. Uji statistik yang digunakan adalah uji regresi logistik berganda dengan model prediksi. 


\section{Hasil dan Pembahasan}

\section{Analisis Univariat}

Tabel 1. Distribusi frekuensi karakteristik responden berdasar kelompok kasus dan kontrol

\begin{tabular}{|c|c|c|c|c|c|}
\hline \multirow[t]{2}{*}{ No } & \multirow[t]{2}{*}{ Karakteristik } & \multicolumn{2}{|c|}{ Kasus } & \multicolumn{2}{|c|}{ Kontrol } \\
\hline & & $\begin{array}{l}\text { Frekuensi } \\
\text { (n) }\end{array}$ & $\begin{array}{c}\text { Persentase } \\
(\%)\end{array}$ & $\begin{array}{c}\text { Frekuensi } \\
\text { (n) }\end{array}$ & Persentase (\%) \\
\hline \multirow[t]{3}{*}{1} & Usia Ibu & & & & \\
\hline & $<20$ atau $>35$ & 66 & 68 & 19 & 19.6 \\
\hline & 20-35 Tahun & 31 & 32 & 78 & 80.4 \\
\hline \multirow[t]{2}{*}{2} & Primipara & 67 & 69.1 & 20 & 20.6 \\
\hline & Multipara \& Grande & 30 & 30.9 & 77 & 79.4 \\
\hline \multirow[t]{3}{*}{3} & Preeklampsi & & & & \\
\hline & $Y a$ & 54 & 55.7 & 20 & 20.6 \\
\hline & Tidak & 43 & 44.3 & 77 & 79.4 \\
\hline \multirow[t]{3}{*}{3} & Anemia & & & & \\
\hline & Ya & 31 & 32 & 11 & 11.3 \\
\hline & Tidak & 66 & 68 & 86 & 88.7 \\
\hline \multirow[t]{3}{*}{4} & Letak Sungsang & & & & \\
\hline & Ya & 19 & 19.6 & 5 & 5.2 \\
\hline & Tidak & 78 & 80.4 & 92 & 94.8 \\
\hline \multirow[t]{4}{*}{5} & Gemeli & & & & \\
\hline & Ya & 10 & 10.3 & 2 & 2.1 \\
\hline & Tidak & 87 & 89.7 & 95 & 97.9 \\
\hline & Jumlah & 97 & 100 & 97 & 100 \\
\hline
\end{tabular}

Berdasarkan Tabel 1, lebih dari setengahnya ibu yang mengalami KPD berusia $<20$ atau $>35$ tahun, riwayat gravida primipara, mengalami preeklamsi. Dan kurang dari setengahnya ibu yang mengalami KPD memiliki riwayat anemia, kehamilan letak sungsang dan gemeli.

\section{Analisis Bivariat}

\section{Hubungan Faktor-Faktor dengan Kejadian Ketuban Pecah Dini}

Tabel 2. Hasil Uji Chi Square Hubungan faktor faktor dengan Kejadian Ketuban Pecah Dini

\begin{tabular}{ccc}
\hline Variabel & P value & OR \\
\hline Usia Ibu & 0,000 & 8.740 \\
Gravida & & $(4.524-16.884)$ \\
8.598 \\
Preeklampsi & 0,000 & $(4.472-16.532)$ \\
Anemia & 0,000 & 4.835 \\
Sungsang & & $(2.564-9.118)$ \\
& 0,001 & 3.672 \\
Gemelli & & $(1.719-7.844)$ \\
& 0,005 & 4.482 \\
& & $(1.600-12.558)$ \\
\end{tabular}

Terdapat hubungan yang signifikan antara variabel usia ibu, gravida, preeklampsi, $(0,000)$, anemia $(0,001)$, sungsang $(0,005)$, gemelli $(0,037)$, dengan kejadian ketuban pecah dini di IGD Maternal RS Drajat Prawiranegara. 


\section{Analisis Multivariat}

Tabel 3. Seleksi Analisis Bivariat antara Variabel Bebas dengan kejadian KPD di RSDP

\begin{tabular}{cccc}
\hline No & Variabel & P value & OR \\
\hline 1 & Usia Ibu & 0.000 & 8.740 \\
2 & Gravida & 0.000 & 8.598 \\
3 & Preeklamsi & 0.000 & 4.835 \\
4 & Anemia & 0.001 & 3.672 \\
5 & Sungsang & 0.004 & 4.482 \\
6 & Gamelli & 0.031 & 5.460 \\
\hline
\end{tabular}

Tabel 4. Analisis Model Multivariat Logistic Regression

\begin{tabular}{|c|c|c|c|c|}
\hline No & Variabel & $\mathrm{p}$ value & OR & Ket \\
\hline \multicolumn{5}{|l|}{ Step 1} \\
\hline 1. & Usia & 0.000 & 6.582 & \\
\hline 1. & Gravida & 0.000 & 8.917 & \\
\hline 2. & Preeklamsi & 0.010 & 2.877 & \\
\hline 3. & Anemia & 0.038 & 2.908 & \\
\hline 4. & Sungsang & 0.014 & 5.620 & \\
\hline 5. & Gameli & 0.198 & 3.289 & Keluar \\
\hline \multicolumn{5}{|l|}{ Step 2} \\
\hline 1. & Usia & 0.000 & 7.058 & $<10 \%$ \\
\hline 2. & Gravida & 0.000 & 8.861 & \\
\hline 3. & Preeklamsi & 0.008 & 2.937 & $<10 \%$ \\
\hline 4 & Anemia & 0.056 & 2.661 & Keluar $>0.05$ \\
\hline 5. & Sungsang & 0.009 & 5.941 & $<10 \%$ \\
\hline \multicolumn{5}{|l|}{ Step 3} \\
\hline 1. & Usia & 0.000 & 7.666 & $<10 \%$ \\
\hline 2. & Gravida & 0.000 & 8.773 & Dominan $<10 \%$ \\
\hline 3. & Preeklamsi & 0.004 & 3.139 & $<10 \%$ \\
\hline 4. & Sungsang & 0.010 & 5.502 & $<10 \%$ \\
\hline
\end{tabular}

Setelah dilakukan analisis dengan cara mengeluarkan satu persatu variabel yang $p$ valuenya $>0,05$ pada step 1 , maka variabel gameli di keluarkan. Pada langkah step 2 didapat nilai Pvalue $>0.05$ pada variabel anemia dengan perubahan nilai OR $<10 \%$ akhirnya model terakhir analisis multivariat dihasilkan semua nilai pvalue $<0.05$, hal ini menyatakan bahwa variabel yang berhubungan signifikan dengan kejadian KPD adalah Usia, Gravida, Preeklamsi, sungsang. Serta variabel yang paling dominan berhubungan dengan KPD adalah Gravida dengan nilai OR 8.773 kali lebih besar dibandingkan dengan variabel lainnya Faktor dominan adalah Gravida.

\section{Pembahasan}

Hasil penelitian yang diperoleh selama penelitian di IGD Maternal RS Drajat Prawiranegara pada bulan Mei 2021 diperoleh:

\section{Frekuensi Kejadian KPD}

Dari 97 kasus dan 97 kontrol pada penelitian ini didapat data $43.8 \%$ ibu dengan usia $<20$ atau $>35$ tahun, ibu dengan gravida multi dan grande $55.2 \%$, ibu dengan preeklamsi $38.1 \%$, ibu dengan anemia $21.6 \%$, ibu dengan kehamilan letak sungsang $12.4 \%$, ibu dengan kehamilan gameli $6.2 \%$.

Dan khususnya pada kasus lebih dari setengahnya ibu yang mengalami KPD berusia $<20$ atau $>35$ tahun, riwayat gravida primipara, mengalami preeklamsi. Dan kurang dari 
setengahnya ibu yang mengalami KPD memiliki riwayat anemia, kehamilan letak sungsang dan gameli.

\section{Hubungan Usia Ibu dengan kejadian KPD}

Berdasarkan analisis bivariat didapatkan hasil Chi Square $\mathrm{p}$ value $0,000 \quad(<0,05)$ berarti ada hubungan yang signifikan antara usia ibu dengan kejadian KPD. Dengan nilai OR 8.7 kali yang artinya bahwa usia ibu memiliki peluang 8.7 kali menyebabkan KPD.

Hal ini sesuai dengan Prawirohardjo (2016) bahwa KPD pada kehamilan prematur disebabkan oleh adanya faktor-faktor diantaranya adalah faktor usia ibu. Hal ini sejalan dengan Sukarni (2015) yang menyatakan bahwa pada usia lebih dari 35 tahun, terjadi penurunan kemampuan organ-organ reproduksi yang berpengaruh pada proses embriogenesis sehingga selaput ketuban lebih tipis yang memudahkan untuk pecah ketuban sebelum waktunya, begitu juga usia <20tahun. Melahirkan pada usia di bawah 20 tahun ternyata 2-5x lebih tinggi risikonya dan meningkatkan kematian maternal. Penelitian yang dilakukan oleh Alim, (2015) menyebutkan bahwa dari 13 ibu yang mengalami KPD, sebanyak 7 ibu (53,8\%) merupakan ibu yang hamil pertama kali (primigravida).

Peneliti pun sependapat bahwa usia ibu memang dapat mempengaruhi kesehatan ibu hamil. Usia matang akan memengaruhi kesiapan mental dan fisik ibu hamil, hal ini menjadi salah satu faktor penentu dalam kesalamatan dan kesiapan persalinan. Mental yang siap dan matang selama masa kehamilan menjadi salah satu faktor pendukung dalam lancarnya proses persalinan normal yaitu power (kekuatan ibu). Keadaan yang baik secara psikologisnya berdampak baik pada kesehatan ibu karena ibu menerima atas kehamilannya, menanti proses kelahirannya, memikirkan akan keselamatannya, dan memengaruhi pola berfikirnya serta memiliki motivasi tinggi dalam menyambut buah hati. Ibu dengan usia matang dan siap secara mental akan mengkonsumsi makanan yang dapat meningkatkan Kesehatan, kebutuhan gizi janin, dan memiliki antusias tinggi dalam memantau kehamilan dengan cara memeriksakan kehamilan sesuai anjuran karena telah siap menjadi ibu. Dalam pemeriksaan kehamilannya, tentunya bidan atau dokter akan memberikan edukasi. Upaya ini yang akan dapat meningkatkan kemampuan ibu dalam menilai kesehatannya, kemampuan dalam menilai tanda-tanda persalinan dan siap akan bersalain. Begitu juga dengan keadaan fisik, seperti pada lazimnya yang telah diungkapkan oleh banyak pakar, bahwa usia yang aman adalah usia 20-35 tahun. Keadaan usia tersebut sudah siap secara fisik yaitu organ reproduksinya.

Usia 20-35 tahun merupakan usia aman untuk kehamilan dan persalinan. Di usia ini, wanita berada pada fase yang alat reproduksinya cukup matang untuk melalui kehamilan dan persalinan. Walaupun kadang kejadian KPD juga bisa terjadi pada usia yang dikatakan aman, namun dalam penelitian terlihat bahwa usia ibu $<20$ tahun atau $\geq 35$ tahun lebih banyak mengalami KPD dibandingkan usia 20-30 tahun pada ibu yang mengalai KPD.

\section{Hubungan Gravida dengan kejadian KPD}

Gravida adalah istilah yang digunakan dalam kebidanan yang artinya seorang wanita yang sedang hamil. Kehamilan adalah suatu keadaan dimana janin dikandung didalam tubuh wanita, yang sebelumnya diawali dengan proses pembuahan dan diakhiri dengan proses persalinan (Prawirohardjo, 2016).

Dalam penelitian ini, terlihat bahwa gravida yang paling banyak muncul pada kejadian KPD (case) yaitu primigravida dengan p_value 0.000 dan nilai OR yang paling dominan dalam analisis multivariat yaitu sebesar 8.7 , artinya gravida ibu bersalin dengan primipara dapat berpeluang meningkatkan kejadian KPD sebanyak 8.7 kali dibandingkan dengan multi \& grandemultipara.

Hal ini sependapat dengan penelitian Sutomo (2013) bahwa keadaan pada hasil analisis secara deskriptif sejalan dengan hasil analisis secara bivariat yang memperoleh nilai $p$ sebesar 0,000 ( $p$ $<\alpha$ ) yang berarti bahwa terdapat hubungan bermakna secara statistik antara paritas ibu dengan kejadian KPD; dengan nilai OR sebesar 2,551 yang berarti bahwa ibu bersalin primipara berisiko hampir tiga kali lebih besar untuk mengalami KPD bila dibandingkan dengan ibu bersalin multipara atau grandemultipara. Didukung oleh Nugroho (2015) yang menyatakan bahwa promigravida menjadi penyebab cukup besar terhadap KPD. Kehamilan pertama merupakan sebuah percobaan yang terberat terhadap kemampuan reproduksi ibu. 
Pengalaman pertama pada ibu primigravida dalam proses persalinan dapat mempengaruhi tingkat kemampuan dalam pemantauan karena kurangnya informasi dan komunikasi ataupun edukasi tentang kehamilan dan persalinan. Seperti dalam pemantauan waktu keluarnya cairan ketuban. Pengalaman persalinan sebelumnya (multi/grande para) dapat mempengaruhi dalam kemampuan menilai cairan pervaginam selama masa kehamilan/proses persalinan. Serta dapat membedakan keluarnya cairan air ketuban dengan buang air kecil. Ibu dengan primigravida juga cenderung merasa cemas dalam masa kehamilannya, sehingga ibu primigravida cenderung mengalami stress dan merupakan faktor yang berkontribusi dalam komplikasi kehamlan maupun komplikasi persalinan.

\section{Hubungan Preeklamsi dengan kejadian KPD}

Berdasarkan hasil penelitian didapatkan nilai $P$ value $0.000(<0.05)$ dan nilai OR 4.8 kali artinya preeklamsi memiliki hubungan yang sangat bermakna dengan kejadian KPD. Dan ibu dengan riwayat preeklamsi memiliki risiko 5 kali untuk mengalami KPD dibandingkan dengan ibu yang tidak preeklamsi.

Preeklamsi memiliki dampak negatif yang sangat besar pada derajat kesehatan ibu dan perinatal, terutama dinegara berkembang. Penyakit ini adalah penyebab utama hampir sepertiga dari 1 juta kematian ibu dinegara-negara berkembang dan merupakan penyumbang proporsi besar dari 6 juta kematian perinatal (Bilano VL, Ota E, Ganchimeg T, 2014). Kumpulan bukti penelitian menunjukkan bahwa kondisi utama dalam patofisiologi preeklamsia adalah kegagalan transformasi fisiologis arteri spiralis, yang menjadi dasar pemikiran terjadinya plasentasi yang memburuk dan berkurang suplai darah ke plasenta pada awal kehamilan. Pada tahapan selanjutnya plasenta akan melepaskan faktorfaktor bioaktif kedalam sirkulasi ibu sehingga menyebabkan disfungsi sel endotel sistemik, perubahan metabolik, adanya pro-trombotik, aktivasi faktor keseimbangan, peradangan intravascular dan kerusakan diberbagai organ (Soto, E, Romero, R, Kusanovic, JP, 2012)

Preeklampsia yang utama adalah vasokontriksi arterial yang menyebabkan kenaikan tekanan darah dan menurunnya pasokan darah yang efektif pada banyak organ serta jaringan tubuh, termasuk plasenta. Plasenta dapat mengalami infark sehingga membatasi jumlah oksigen dan nutrien yang tersedia bagi bayi. Retardasi pertumbuhan intrauteri dapat terjadi dan keadaan hipoksia dapat membuat janin tidak mampu untuk menahan stres persalinan yang normal yang dapat menyebabkan ketuban pecah dini. Hasil penelitian Ayu (2018), menunjukkan bahwa terdapat hubungan antara preeklampsia dengan kejadian ketuban pecah dini dengan $p$ value $=0.023(p<0,05)$.

Kejadian preeklampsia akan meningkat pada kehamilan kedua bila ada kehamilan dengan jarak anak yang terlalu jauh. Dalam penelitian Nelawati (2014) disampaikan bahwa bila ada riwayat hipertensi (preeklampsi-eklamsi) maka kemungkinan pada primigravida akan meningkat empat kali. Kejadian ini dapat diminimalisir dengan dilakukannya penyuluhan pada setiap ibu hamil untuk dapat mengetahui tanda-tanda bahaya yang bisa saja terjadi pada saat hamil, terlebih kepada ibu hamil yang mempunnyai riwayat hipertensi sebelumnya agar bisa lebih memperhatikan makanan, kesehatan ibu dan janin serta rajin melakukan kontrol kehamilan kepada tenaga kesehatan.

Melihat dari data hasil analisis univariat dan bivariat, terlihat bahwa lebih dari setengahnya pada kasus KPD memang memiliki usia $<20$ atau $>35$ tahun dan status paritas primipara hal ini dapat menunjukkan bahwa usia dan gravida pada kelompok kasus belum bisa d katakan matang atau belum siap. Seperti sudah disampaikan sebelumnya pada pembahasan 2 variabel tersebut diatas, usia sangat mempengaruhi kesiapan ibu dalam menghadapi kehamilan dan persalinan. Kesiapan mental dapat dibuktikan dari keseriusan atau ketaatan dalam melakukan kunjungan ANC. Salah satu tujuan dari kunjungan ANC adalah mengetahui adanya komplikasi. Kegiatan pemeriksaan yang rutin diberikan mulai dari pemeriksaan kenaikan BB ibu, mengukur LILA, mengukur tekanan darah, memantau TFU, menghitung usia kehamilan, pemeriksaan penunjang seperti protein urin, reduksi, dan edukasi dalam mempersiapkan persalinan yang aman.

Hal ini mungkin yang belum terfikirkan oleh usia tersebut diatas dan ketidaktauan/kurangnya informasi atas pengalaman yang kurang oleh kelompok primipara.

\section{Hubungan Anemia dengan kejadian KPD}

Berdasarkan hasil analisis bivariat didapatkan bahwa nilai $P$ value $=0.001 \quad(<0.05)$ dengan nilai $\mathrm{OR}=3.67$ artinya terdapat hubungan yang bermakna antara anemia dengan kejadian KPD. Ibu 
hamil dengan anemia berisiko 4 kali untuk mengalami persalinan dengan KPD. Hal ini sesuai dengan hasil penelitian Wulandari (2016), ibu yang mengalami anemia berisiko 3,33 kali lebih tinggi untuk mengalami KPD dibandingkan dengan ibu yang tidak mengalami anemia. Hasil penelitian sejalan dengan Allen, (2011) yang menyatakan bahwa anemia dapat menyebabkan hipoksia dan defisiensi besi sehingga merangsang sintesis corticotoprin releasing hormone (CRH). Konsentrasi $\mathrm{CRH}$ merupakan peningkatan faktor risiko utama untuk persalinan dengan KPD.

Pada kehamilan relatif terjadi anemia karena darah ibu hamil mengalami hemodelusi atau pengencangan dengan peningkatan volume 30\% sampai $40 \%$ yang puncaknya pada kehamilan 32 sampai 34 minggu. Pada ibu hamil yang mengalami anemia biasanya ditemukan ciri-ciri lemas, pucat, cepat lelah, mata berkunang-kunang. Pemeriksaan darah dilakukan minimal 2 kali selama kehamilan yang pada trimester pertama dan trimester ke tiga. Dampak anemia pada janin antara lain abortus, terjadi kematian intrauterin, prematuritas, berat badan lahir rendah, cacat bawaan dan mudah infeksi. Pada ibu, saat kehamilan dapat mengakibatkan abortus, persalinan prematuritas, ancaman dekompensasikordis dan ketuban pecah dini (Manuaba I Gde, 2012).

\section{Hubungan Letak sungsang dengan kejadian KPD}

Berdasarkan hasil analisis bivariat didapat nilai $P$ value $=0.005(<0.05)$ Artinya terdapat hubungan yang bermakna antara letak sungsang dengan kejadian KPD dan terdapat nilai OR sebesar 4.4 kali artinya letak sungsang memiliki risiko mengalami kejadian KPD sebanyak 4 kali. Hal ini sesuai dengan penelitian (Ridwan, 2014) ada hubungan antara kelainan letak janin dengan ketuban pecah dini ( pvalue $=0,005<\alpha)$. Hasil analisis diperoleh nilai $\mathrm{OR}=$ 3,5 artinya ibu dengan kelainan letak janin memiliki resiko 3 kali lebih terjadi ketuban pecah dini saat bersalin dibanding dengan ibu yang tidak mengalami ketuban pecah dini.

Hasil penelitian ini sesuai dengan penelitian Ramlis (2013), mengenai hubungan kelainan letak janin dengan kejadian ketuban pecah dini di RSUD DR. M. Yunus Bengkulu diperoleh $p$ value $=0.025$ yang artinya terdapat hubungan antara kelainan letak janin dengan kejadian ketuban pecah dini. Selain itu diperoleh pula $\mathrm{OR}=2,442$ artinya ibu yang mengalami kelainan letak janin saat kehamilan akan beresiko sebesar 2,4 kali mengalami ketuban pecah dini dibanding dengan ibu yang tidak mengalami kelainan letak janin.

Hal yang sama ditemukan oleh Aprilia (2017), dalam penelitiannya menemukan adanya hubungan antara kelainan letak janin dengan kejadian ketuban pecah dini ( $p$ value $=0,000$ ). Wulandari (2016) menyatakan bahwa terdapat hubungan antara kelainan letak janin dengan kejadian ketuban pecah dini $(p<0,05 ; O R=6,942$ (Cl 95\%: $1,139-42,325)$ ). Artinya ibu yang mengalami kelainan letak janin berisiko 6,942 kali lebih besar untuk mengalami ketuban pecah dini dibandingkan dengan ibu yang tidak mengalami kelainan letak janin.

Kelainan letak janin (malpresentasion) dapat menjadi salah satu faktor kejadian KPD. Salah satu contoh malpresentasion adalah letak sungsang. Pada letak sungsang, bokong menempati serviks uteri, dengan keadaan ini pergerakan janin terjadi dibagian terendah karena keberadaan kaki janin yang menempati daerah serviks uteri sedangkan kepala janin akan mendesak fundus uteri yang dapat menekan diafragma dan keadaan ini menyebabkkan timbulnya rasa sesak pada ibu hamil yang dapat meningkatkan ketegangan tekanan intra uterin sehingga menyebabkan terjadinya KPD.

\section{Hubungan Gamelli dengan kejadian KPD}

Berdasarkan hasil analisis bivariat didapatkan nilai Pvalue $=0.037 \quad(<0.05)$ yang artinya tedapat hubungan bermakna antara kehamilan ganda/gamelli dengan kejadian KPD. Dan terdapat nilai OR 5.4 yang artinya kehamilan ganda/gamelli memiliki resiko 5.4 kali mengalami KPD. Hal ini sesuai dengan hasil penelitian Tahir, suriani, Arifin seweng, (2012) menunjukkan bahwa terdapat hubungan antara kehamilan janin ganda dengan kejadian ketuban pecah dini $(p<0,00 ; O R=3,0(\mathrm{Cl}$ 95\%: $1,30-7,01$ ). Artinya ibu dengan kehamilan janin ganda lebih berisiko 3,0 kali lebih besar untuk mengalami ketuban pecah dini dibandingkan dengan ibu bayi tunggal. Gemelli/Kehamilan kembar dalah suatu kehamilan dua janin atau lebih. Begitu juga hasil penelitian (Ridwan, 2014) Terdapat hubungan antara kehamilan ganda dengan ketuban pecah dini ( $p$ value $=0,001$ ) dan ada hubungan antara kelainan letak janin dengan ketuban pecah dini ( $p$ value $=0,005)$. 
Menurut Manuaba I Gde (2012), kehamilan ganda atau kehamilan kembar adalah kehamilan dengan dua janin atau lebih, frekuensi kehamilan kembar condong meningkat. Janin kembar dua biasanya terjadi akibat pembuahan dua ovum terpisah disebut kembar dizigot atau fraternal. Meskipun lebih jarang, kembar dua dapat berasal dari satu ovum yang dibuahi yang kemudian terbelah disebut kembar monozigot atau identik (Cunnigham, 2013).

Menurut Manuaba I Gde (2012), salah satu penyebab terjadinya ketuban pecah dini adalah ketegangan rahim berlebihan seperti kehamilan ganda/kembar. kehamilan ganda merupakan kehamilan dengan ukuran uterus yang lebih besar dibanding umur kehamilannya, sehingga terjadi keregangan rahim berlebihan. Hal tersebut akan meningkatkan tekanan intrauterin, dengan tekanan yang berlebihan ini vaskularisasi tidak berjalan dengan lancar yang dapat mengakibatkan selaput ketuban kekurangan jaringan ikat. Sehingga menyebabkan selaput ketuban tidak kuat atau lemah dan bila terjadi sedikit pembukaan servik saja maka selaput ketuban akan mudah pecah.

Sependapat dengan teori diatas Nugroho (2015), juga mengatakan bahwa faktor predisposisi ketuban pecah dini yaitu tekanan intra uterin yang meninggi atau meningkat secara berlebihan (overdistensi uterus) salah satunya dikarenakan kehamilan ganda/gamelli. Hasil penelitian Lismawati, (2012) menunjukkan bahwa faktor yang mempengaruhi terjadinya KPD pada ibu hamil trimester III di RS Ban Lawang adalah faktor kehamilan janin ganda yang berkontribusi sebesar $4,83 \%$.

\section{Simpulan}

Kejadian KPD lebih besar gerjadi pada usia $<20$ atau $>35$ tahun (66\%), ibu primipara (67\%) dan ibu dengan preekalmpsi. Terdapat hubungan usia ibu, gravida, pre eklampsi, anemia, sungsang, gemelli dengan kejadian KPD di IGD Maternal RS Drajat Prawiranegara. Gravida merupakan faktor paling dominan yang berhubungan dengan kejadian KPD.

\section{Ucapan terima kasih}

Terimakasih kepada Politeknik Kesehatan Aisyiyah Banten yang telah mendanai penelitian Internal pendanaan 2020,

\section{Daftar Pustaka}

Al-Hussain, Tarek Khalaf, Sahar Nagieb Mohamed, Hamida Alam El-dien, and A. A. E. A. (2012). Cervical During Pregnancy and Its Relation to Preterm Pre-Labour Rupture Of Membranes. Journal of American Sciences, 8(12), 364-373.

Alim, Z. dan Y. A. S. (2015). Faktor Yang Mempengaruhi Kejadian Ketuban Pecah Dini Pada Ibu Hamil Trimester III di Rumah Sakit Bantuan Lawang. Jurnal Hesti Wira Sakti, 4, no.1.,(1), 101-109.

Allen, L.-. (2011). Biological Mechanisms That Might Underlie Iron's Effects on Fetal Growth and Preterm Birth. The Journal of Nutritional Sciences, 131(1), 581-589.

Antonius. (2017). Perawatan Ketuban Pecah Dini. Jakarta: Muha Medika.

Aprilia. (2017). Faktor ibu bersalin yang mengalami ketuban pecah dini di RSUD Bangking tahun 2017. PREPOTIF JURNAL KESEHATAN MASYARAKAT.

Ayu, F. (2018). Faktor-faktor yang berhubungan dengan kejaian ketuban pecah dini pada ibu hamil yang melakukan persalinan di RSUD.H.Abdoel Madjid Batoe Batanghari. Jambi.

Bilano VL, Ota E, Ganchimeg T, et al. (2014). Risk Factors of Pre-Eclampsia/ Eclampsia and Its Adverse Outcomes in Low- and MiddleIncome Countries: A WHO Secondary Analysis. PLOS ONE, 9(3), e91198.

Cunnigham, G. (2013). Obstetri Williams. Jakarta: EGC.

Lismawati, L. (2012). Faktor-Faktor yang Mempengaruhi Kejadian Ketuban Pecah Dini pada Ibu Hamil Trimester III di Rumah Sakit Bantuan Lawang. [Naskah Publikasi]. Malang.

Manuaba I Gde. (2012). Ilmu Kebidanan, Penyakit Kandungan, dan KB. Jakarta: EGC.

Mochtar, R. (2012). Sinopsis Obstetri: Obstetri Fisiologi, Obstetri Patologi. Edisi III. Jakarta: EGC.

Nelawati. (2014). Faktor-faktor yang berhubungan dengan kejadian hipertensi pada ibu hamil yaitu umur, paritas dan riwayat hipertensi (preeklamsi-eklamsi). 
Nugroho, S. (2015). Obstetri dan ginekologi. Yogyakarta: Nuha Medika.

Prawirohardjo, S. (2016). IImu Kebidanan. Jakarta: Bina Pustaka Sarwono.

Purba, D. M. (2015). Faktor - Faktor yang Berhubungan dengan Kejadian Komplikasi dan Persalinan di Rumah Sakit Umum Daerah (RSUD) Kota Depok Tahun 2012. Jakarta.

Ramlis, R. (2013). Hubungan kelainan letak janin dengan kejadian ketuban pecah dini di Ruang Kebidanan RSUD DR. M. Yunus Bengkulu. Jurnal Kesehatan Stikes Dehasen.

RI, K. K. R. R. from kementerian kesehatan. (2017). Kementerian Kesehatan RI. Retrieved from kementerian kesehatan RI. Retrieved from website: http://www.kemkes/go.id

Ridwan, M. dan H. (2014). Hubungan Kehamilan Ganda dan Kelainan Letak Janin dengan Kejadian Ketuban Pecah Dini di RSUD Demang Sepulau 106 Raya Lampung Tengah. Jurnal Kesehatan Metro, Vol. 7, no(2), 21-25.

Saifudin, A. B. (2017). Ilmu Kebidanan Edisi Keempat Cetakan Ketiga. Jakarta: YBPSP.
Soto, E, Romero, R, Kusanovic, JP, et al. (2012). Late-onset preeclamsia is the is associated with an imbalance of angiogenic and antiangiogenic factors in patients with and without placental lesions consistent with maternal underperfusion. Journal of Maternal and Fetal Neonatal Medicine. NIH Public Access., May; 25(5)(May; 25(5): 498507).

Sukarni. (2015). Kehamilan,persalinan, dan nifas. Jakarta: Medical.

Tahir, suriani, Arifin seweng, Z. A. (2012). Faktor determinan ketuban pecah dini di RSUD Syekh Yusuf kabupaten Gowa.

Wulandari, E. (2016). Analisis Faktor Risiko Terhadap Kejadian Ketuban Pecah Dini pada Ibu Melahirkan di RSUD Tugurejo Semarang. [Skripsi]. . Universitas Muhammadiyah Semarang, Semarang. 